\title{
Paleomagnetism of the Lower Devonian Traveler Felsite and the Acadian orogeny in the New England Appalachians
}

DANN J. SPARIOSU Department of Geological Sciences and Lamont-Doherty Geological Observatory, Columbia University, DENNIS V. KENT Palisades, New York 10964

\section{ABSTRACT}

A suite of felsic extrusive rocks from the Lower Devonian Traveler Felsite, northcentral Maine $\left(46.1^{\circ} \mathrm{N}\right.$ lat., $68.9^{\circ} \mathrm{W}$ long.) was collected for paleomagnetic study: 28 samples from 5 sites in the (lower) Pogy member, 56 samples from 10 sites in the (upper) Black Cat member, and 13 samples from 10 cobbles in the basal conglomerate of the overlying Trout Valley Formation. Characteristic magnetizations based on AF demagnetization analyses and supported by thermal studies give a formation mean direction, after simple correction for bedding tilt, of $\mathrm{D}=25.2^{\circ}, \mathrm{I}=-20.2^{\circ}, \alpha_{95}=10.6^{\circ}$ for 13 sites in the Traveler Felsite. The occurrence of normal and reversed magnetozones under stratigraphic control and the antiparallel directions of the polarity units following the tilt correction indicate an acquisition of remanence near the time of formation of the rock units. The mean direction corresponds to a (south) paleopole position of $29^{\circ} \mathrm{S}$ lat., $262^{\circ} \mathrm{E}$ long. $\left(\delta_{\mathrm{p}}, \delta \mathrm{m}=\right.$ $\left.6^{\circ}, 11^{\circ}\right)$ for the Traveler Felsite.

This pole position is in close agreement with poles from two other rock units of similar age from the same lithostratigraphic belt in the northern Appalachians. The mean of these three poles is distinct from Late Silurian and Middle Devonian poles from cratonic North America (Laurentia) and from Early Devonian results from the Acadia displaced terrane, suggesting that this area constituted a separate tectonic unit during the Early Devonian. We propose a tectonic model in which a "Traveler terrane" is rotated $20^{\circ}$ to $30^{\circ}$ while converging with Laurentia and undergoing deformation during the Early to Middle Devonian Acadian orogeny.

\section{INTRODUCTION}

Evidence that a displaced terrane may have played a significant role in the development of the northern Appalachians has been presented in analyses of paleomagnetic data from upper Paleozoic rocks of North America (Kent and Opdyke, 1978, 1979, 1980; Van der Voo and others, 1979; Irving, 1979). However, the geographical extent of the Acadia displaced terrane and its location with respect to cratonic North America (Laurentia) during the Early Devonian remain poorly defined because of a lack of paleomagnetic data for this time period. Although the Lower Devonian Traveler Felsite in north-central Maine was selected for paleomagnetic study in an attempt to address these problems, our results can be inferred to identify the presence of a previously unidentified rotated tectonic element in the northern Appalachians.

\section{Geologic Setting}

The Traveler Felsite is the largest of a chain of Siluro-Devonian felsic volcanic bodies extending from northern New Hampshire to northeastern New Brunswick (Rankin, 1961; Osberg, 1978). A section as much as $3,000 \mathrm{~m}$ thick of extrusive rocks of predominantly rhyodacitic composition is exposed in the Traveler Mountain Quadrangle, Maine (Figs. la and $1 \mathrm{~b}$ ). Rankin (1961, 1968) extensively mapped the area and divided the formation into a lower Pogy member and upper Black Cat member on the basis of lithologic character. Ash-fall tuffs of the basal Pogy member grade upward from the Matagamon Sandstone, which contains shallow-marine fauna of Oriskany age (Early Devonian) (Rankin,
1961). Unconformably overlying the upper Black Cat member is the Trout Valley Formation, a fluvial to shallow-marine sandstone containing plant fossils of probable Schoharie age (late Early Devonian) (Dorf and Rankin, 1962). The basal part of the Trout Valley Formation (Gifford lentil) is a conglomerate containing almost exclusively felsite cobbles (Rankin, 1961). These stratigraphic relationships tightly constrain the Early Devonian age of the Traveler Felsite. A Rb-Sr whole-rock age of $360 \pm 10$ m.y. has been determined for the felsite (Bottino and others, 1965), somewhat young considering the stratigraphic constraints. However, no evidence of extensive reheating has been found in either the felsite or the overlying sandstones.

The Devonian history of the area according to Rankin (1961) is as follows: (1) deepwater deposition of the Seboomook Formation; (2) shoaling and deposition of the Matagamon Sandstone; (3) explosive subaerial eruption of the Pogy member; (4) caldera collapse and related deformation; (5) explosive eruption of the Black Cat member, caldera subsidence and doming; (6) uplift, erosion, and deposition of the Trout Valley clastics; (7) gentle folding of the section along east-west trends during the Acadian orogeny; (8) Middle to Late Devonian intrusion of the Katahdin Granite, exposed in the southern part of the quadrangle; (9) minor strike-slip and normal faulting of unknown age. No record exists of events between these and the Pleistocene glaciation that exposed much of the bedrock.

A total of 83 oriented drill core samples was taken from 15 sites in the Traveler Felsite, including 5 sites in the Pogy member and 10 in the Black Cat (Fig. 1b). Addition- 


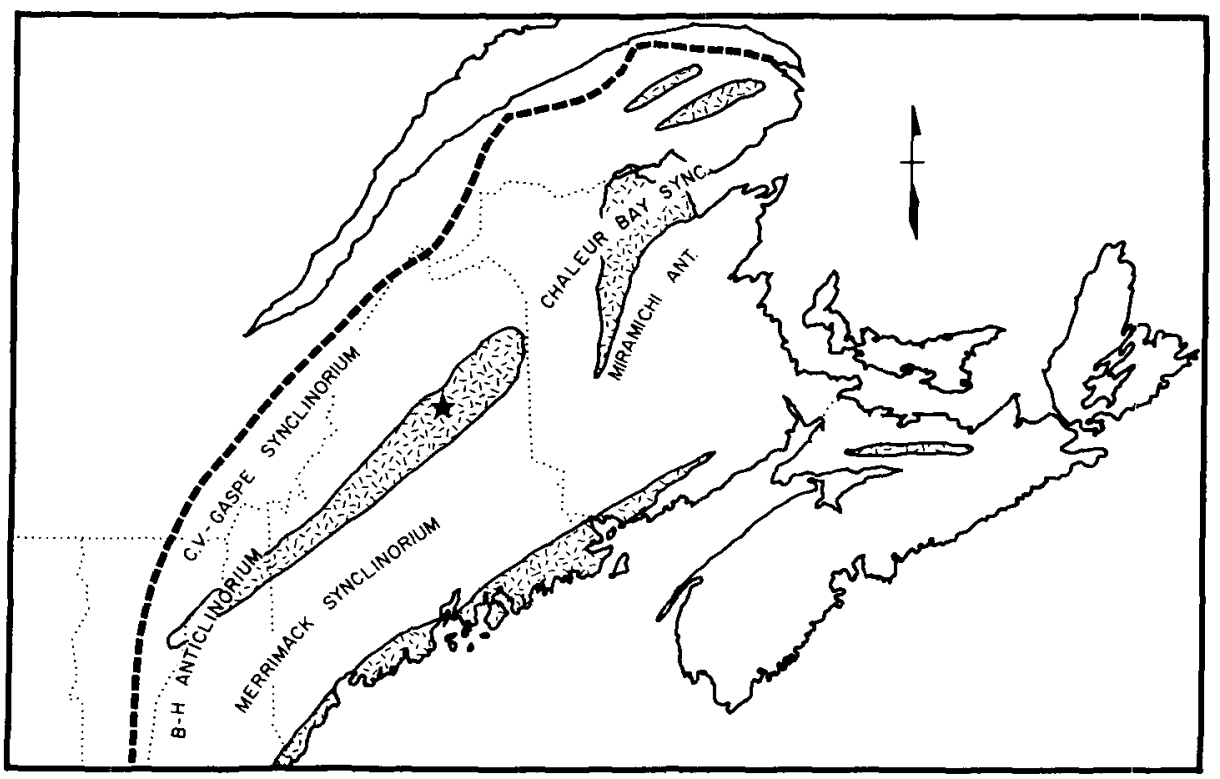

a

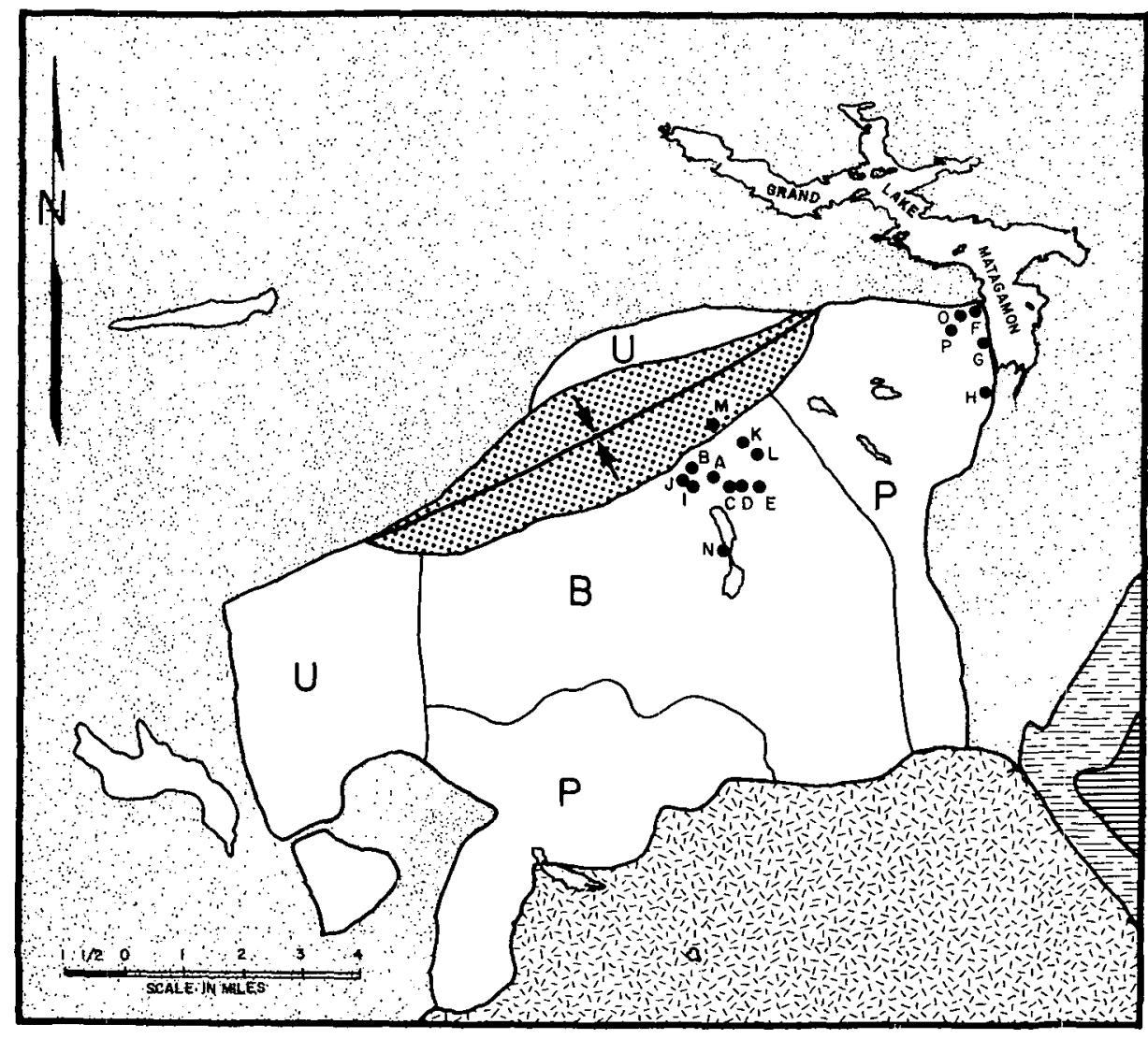

b

ally, 13 cores were drilled from 10 felsite cobbles in the Gifford conglomerate of the Trout Valley Formation. Bedding orientations were measured on site whenever possible and, where less obvious (at 3 sites),
Figure 1. a. Map (modified from Osberg, 1978) showing location of Traveler Quadrangle (star), generalized belts of SiluroDevonian felsic volcanics (stippled), and westward limit of Acadian deformation (dashed line). Also indicated are the axes of the major structural features, including the Connecticut Valley-Gaspé Synclinorium and the Bronson Hill (B-H) Anticlinorium. b. Simplified geologic map of Traveler Mountain area with locations of paleomagnetic sampling sites (modified from Caldwell, 1972). Also shown is the axis of the Trout Valley Syncline (Rankin, 1961).

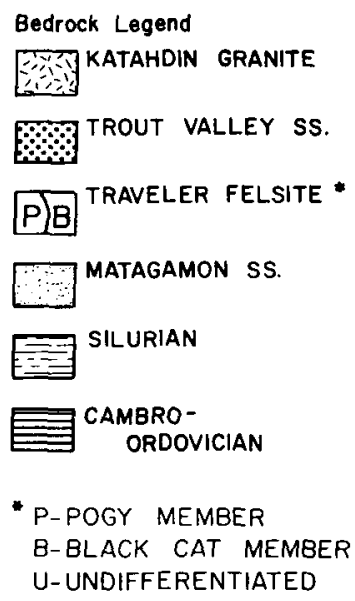

glomerate (DTM), whereas all other samples were hard, aphanitic "rhyolites" with weathering rinds of only a few millimetres in thickness.

\section{MAGNETIC MEASUREMENTS- NRM}

Natural remanent magnetization (NRM) intensities range from $1 \times 10^{-3} \mathrm{~A} / \mathrm{m}$ to $4 \times$ $10^{-1} \mathrm{~A} / \mathrm{m}$ in the felsites and in the conglomerate cobbles from $5 \times 10^{-5} \mathrm{~A} / \mathrm{m}$ to $3 \times 10^{-4}$ $\mathrm{A} / \mathrm{m}$. Koenigsberger ratios range from 0.5 to 3.0 in most sites, with notable exceptions from DTB and DTP $(0.1$ to 0.3$)$ and the cobbles (on the order of 0.001 ). In situ NRM directions (Fig. 2) show two major groupings, those from the Black Cat member in the northeast quadrant and Pogy member samples in the southwest with steeper inclinations. No samples have NRM directions near the present-day field direc- 
TRAVELER NRM

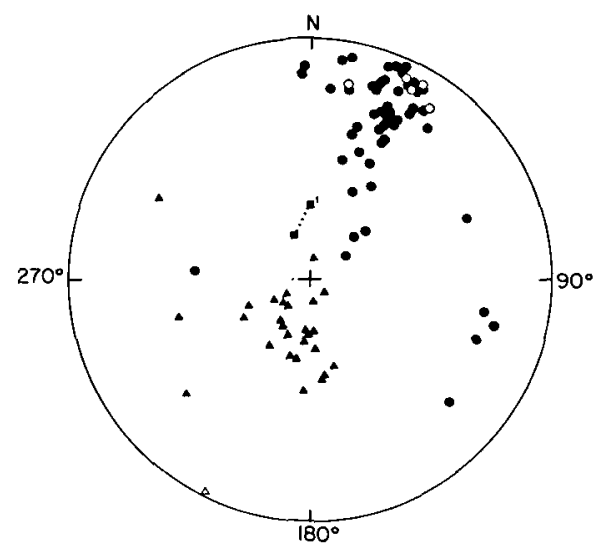

Figure 2. Equal-area plot of sample NRM directions. Filled (open) symbols are plotted on the lower (upper) hemisphere. Circles = Black Cat member; triangles = Pogy member; filled square and square prime are present-day geomagnetic field direction and axial geocentric dipole direction for the sampling locality.

tion. All samples were subjected to progressive alternating field (AF) demagnetization, thermal demagnetization, or a combination of the two techniques, for discrimination of magnetization components.

\section{Demagnetization Analyses}

Black Cat Member. The response of the samples to progressive AF demagnetization is generally quite uniform. Vector end-point diagrams (Zijderveld, 1967) illustrate the initial removal of a magnetic component with steep, positive inclinations and declinations scattered about geographic North (Fig. 3a). Although the relative contribution of this component to the total NRM vector varies from site to site, remanent coercivities are consistently in the 15 to 40 millitesla (mT) range. The low coercivities and general grouping of these initial component directions around the present field are consistent with a viscous magnetization.

At higher fields, almost all samples show a linear trend toward the origin. The exceptions are samples from site DTB (deeply weathered tuffs) that do not yield coherent directions and are not considered further. This higher coercivity, more stable magnetization typically has a northeasterly declina-

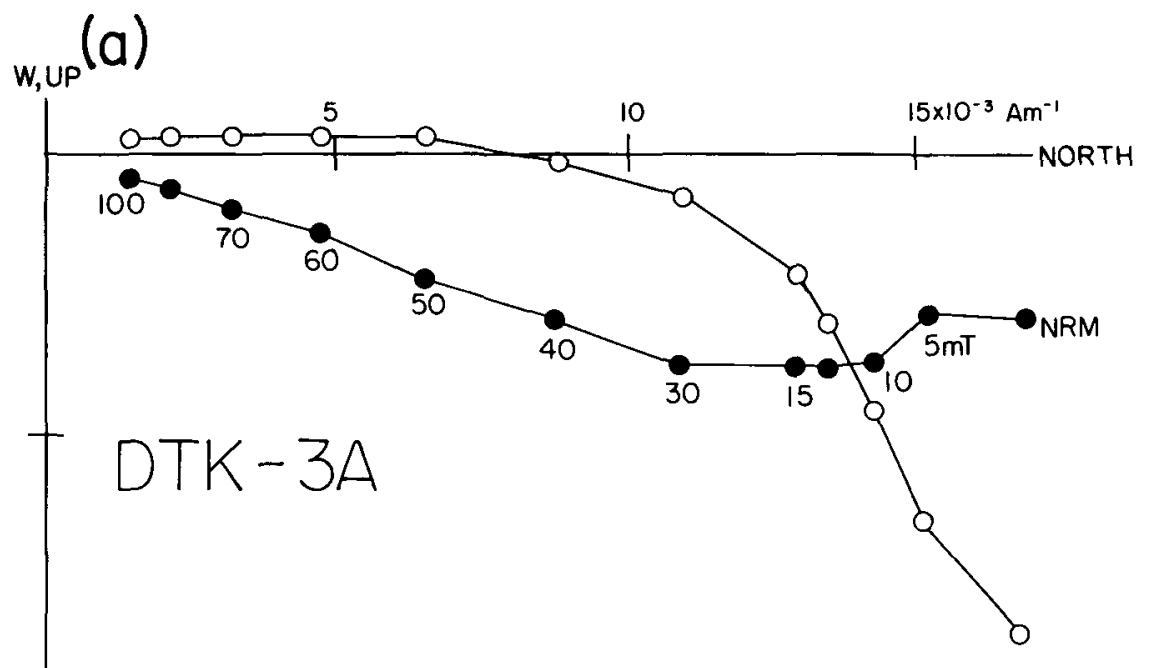

(b)

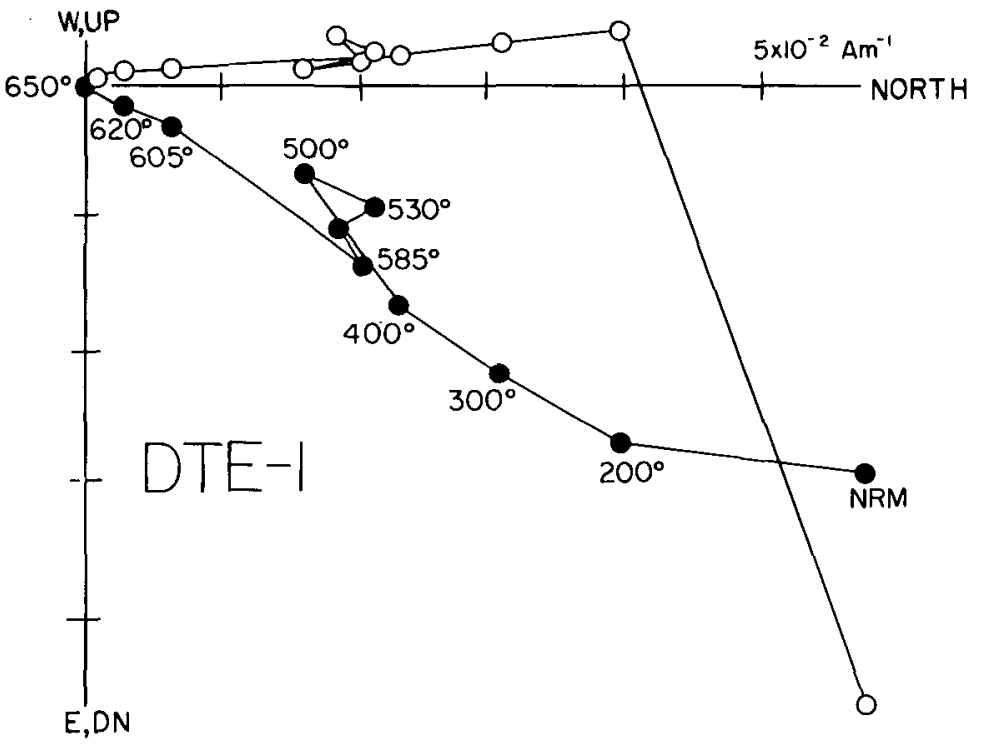

Figure 3. Orthogonal demagnetization diagrams for representative specimens from the Black Cat member. Filled circles are projections on the horizontal plane; open circles are on the north-south vertical plane. No correction for bedding tilt is applied. a. Alternating field demagnetization; field strengths are in millitesla $(\mathrm{mT})$. b. Thermal demagnetization with temperatures in degrees centigrade.

tion with a shallow negative inclination and is found in the other 9 sites sampled in the Black Cat member.

Samples selected for detailed progressive thermal demagnetization included pilot samples from most sites and two samples from DTD and DTE that still had substantial remanences remaining following AF demagnetization to $100 \mathrm{mT}$ and $60 \mathrm{mT}$, respectively (Fig. $3 b$ ). The same magnetiza- tion components identified with AF demagnetization are observed in the thermal procedures. Trajectories between NRM and $200{ }^{\circ} \mathrm{C}$ treatments appear to be intermediate between the high-coercivity and lowcoercivity viscous components revealed during the AF studies. With demagnetization to higher temperatures, the sample magnetizations decay linearly to the origin with directions parallel to the high-coer- 
civity direction. The blocking temperature spectra show a concentration usually between 500 to $600{ }^{\circ} \mathrm{C}$, with intensities decaying to $0 \%$ to $5 \%$ of the NRM value at temperatures of $600{ }^{\circ} \mathrm{C}$, and thus suggest that magnetite is the carrier of remanence. The only notable difference between AF and thermal demagnetization curves appears in the 500 to $585{ }^{\circ} \mathrm{C}$ range of two specimens where an apparent magnetic component approximately antipodal to the high-coercivity, high-blocking temperature component is removed (Fig. 3b). This may represent a partial overprint acquired in a reversed field near the time of acquisition of the dominant normal magnetization, although the low frequency of occurrence and the limited temperature range prohibit good resolution of this component.

Pogy Member. Progressive alternating field demagnetization of Pogy member samples removes first a low-coercivity component similar to that observed in the Black Cat member (northerly declinations, steep positive inclinations), followed by removal of a reversed component (southerly declination, positive inclination) that is roughly antiparallel to the high-coercivity component of the Black Cat (Fig. 4a). In some cases (Fig. 4b), curving demagnetization trajectories reveal considerable overlap of the coercivity spectra of the high- and lowcoercivity components. In other cases (sites DTF, DTH, DTO), the reversed component decays in an apparently linear manner but does not trend toward the origin at AF fields as great as $100 \mathrm{mT}$ (Fig. 4c). Subsequent progressive thermal demagnetization of these specimens to $685^{\circ} \mathrm{C}$ reveals unstable behavior in some (site DTP) and removal of a higher blocking-temperature component in others (site DTO). The additional component is evident at temperatures between 585 and $680^{\circ} \mathrm{C}$ and has a direction subparallel to the low-coercivity component. We think that it may be a chemical remanent magnetization acquired during recent weathering of the outcrop. The fact that it is observed only in Pogy member samples is due perhaps to the fact that they are porous welded tuffs.

Samples subjected to thermal demagnetization only (Fig. 4d) again reveal the presence of components similar to those identified in AF demagnetization, although the $>600{ }^{\circ} \mathrm{C}$ component was not well isolated in any of these. Again, blocking tempera-
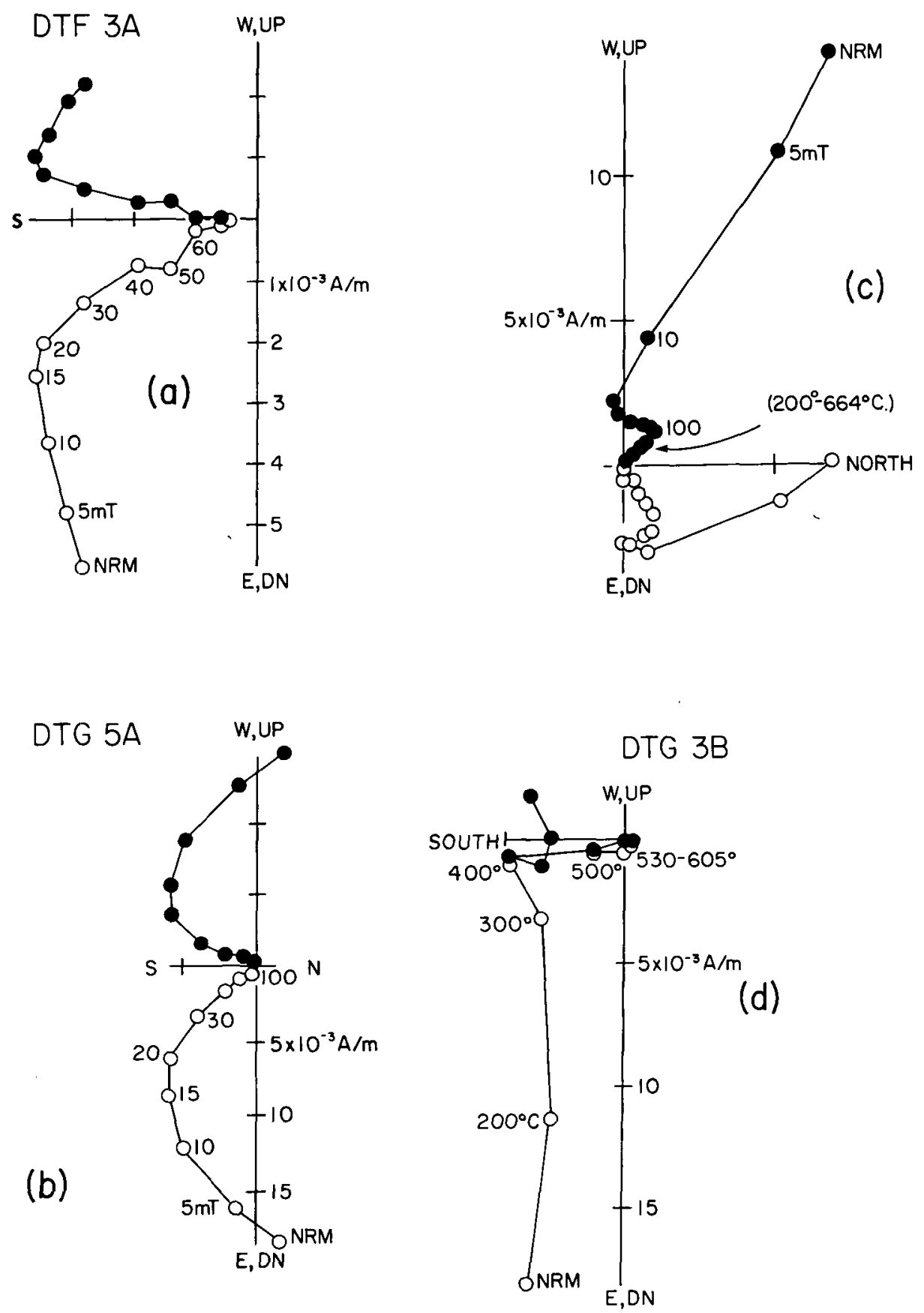

Figure 4. Representative demagnetization diagrams for specimens from the Pogy member. Axes and symbols labeled as in Figure 3. a. AF demagnetization showing discrete separation of low- (NRM-20mT) and high- (30-80 mT) coercivity magnetization components. b. Same, illustrating the curving trajectory associated with overlap of the coercivity spectra of the two components between $5 \mathrm{mT}$ and $30 \mathrm{mT}$. c. AF and thermal demagnetization for an example in which the high-coercivity component does not decay to the origin. Subsequent thermal demagnetization removes the remaining high-temperature component with a direction near the present-day magnetic field. $d$. Thermal demagnetization revealing discrete separation of the same two components observed during AF demagnetization. 
TABI.E I. SITE MEAN CHARACTERISTIC DIRECTIONS OF THE TRAVELER FELSITE

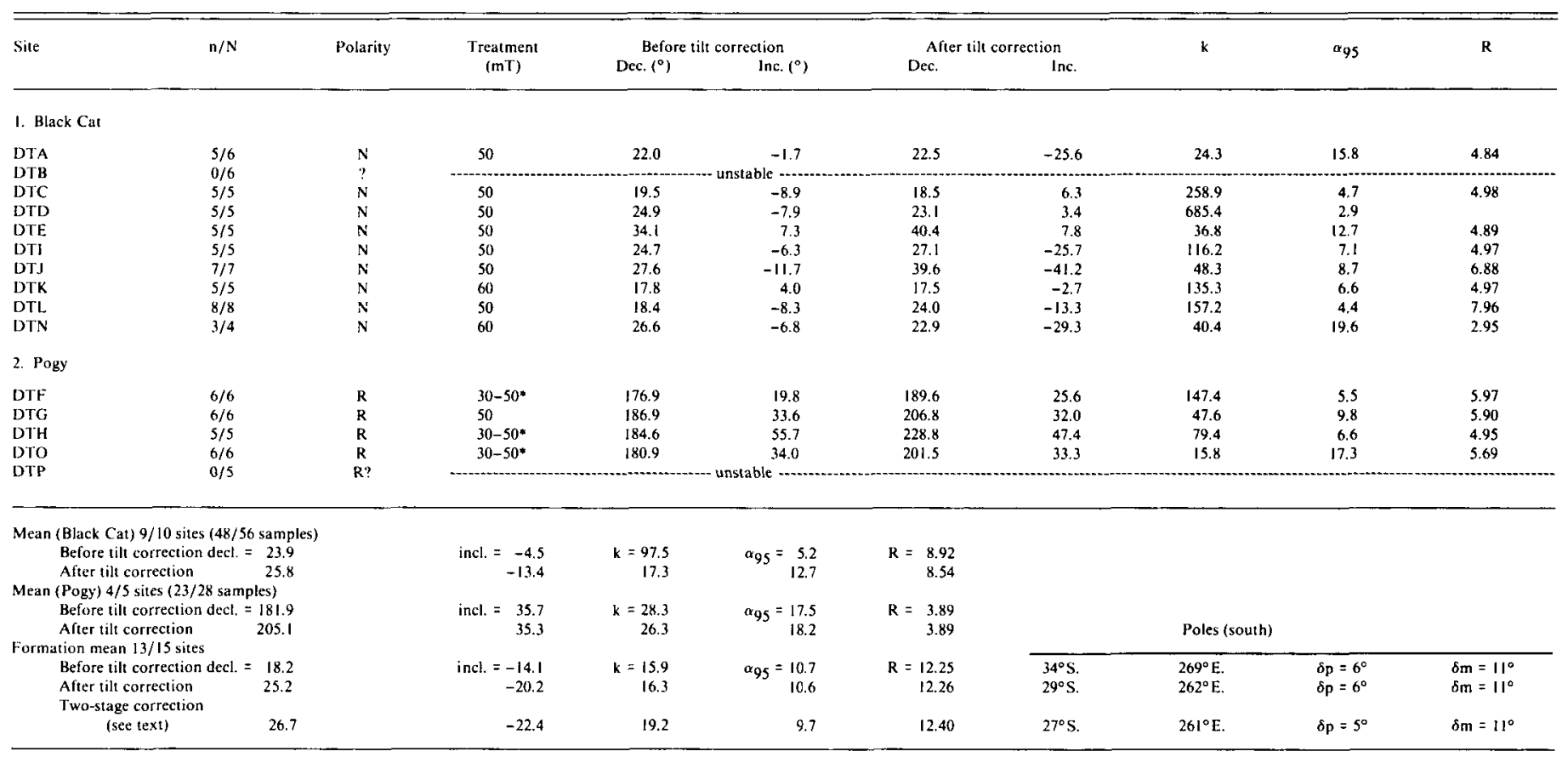

Nore: $\mathrm{n} / \mathrm{N}$ is number of samples used in site mean calculation over total number; treatment refers to demagnetization level from which directions were used for calculation; $\mathrm{k}$ is the estimate of Fisher's precision parameter,

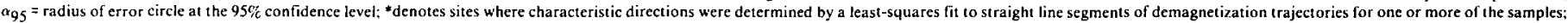
$R$ is the length of the resultant vector; poles calculated for site latitude $=46.1^{\circ} \mathrm{N}$, longitude $=68.9^{\circ} \mathrm{W}$.

tures indicate the dominance of magnetite. One sample (DTF-2) shows evidence of a partial normal overprint on the dominant reversed component between 530 and 585 ${ }^{\circ} \mathrm{C}$, the opposite of the phenomenon described above in a sample from the Black Cat member.

Gifford Conglomerate. The stratigraphic

(a)

(b)

relationship between the Gifford conglomerate (basal Trout Valley Formation) and the underlying felsite presents an opportunity to apply the conglomerate test of Graham (1949). To this end, progressive AF and thermal demagnetization studies were carried out on 13 samples from 10 felsite cobbles within the conglomerate. Although

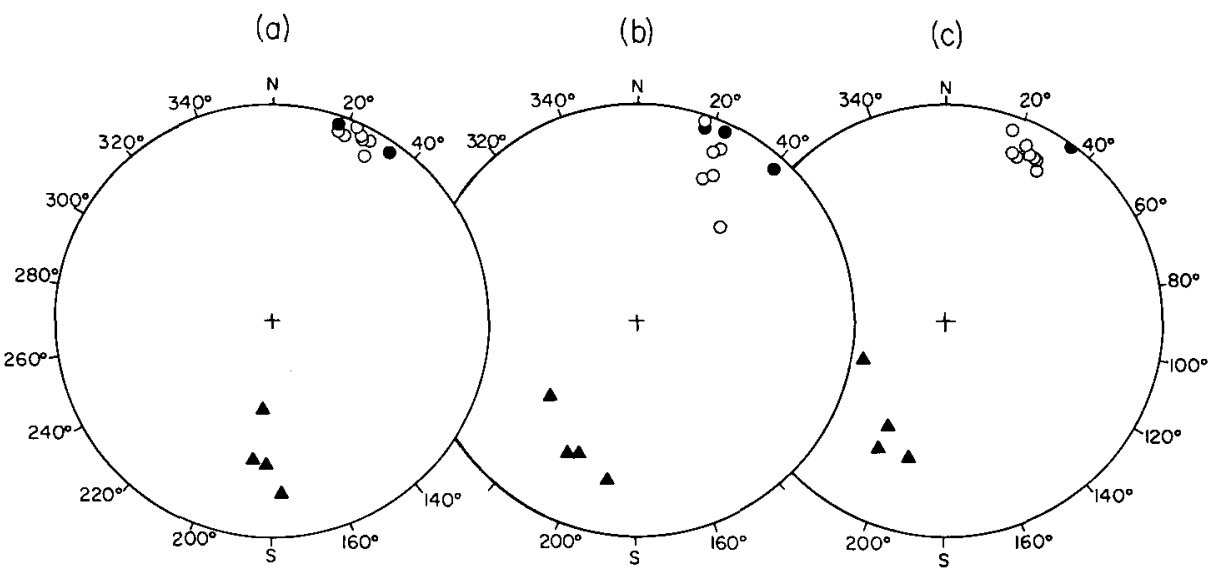

Figure 5. Equal-area plots of site mean characteristic directions of the Traveler Felsite. Circles are sites from the Black Cat member, triangles from the Pogy member. a. In situ directions. b. Directions after simple rotation about bedding strike. c. After two-stage structural correction (see text for description).
NRM directions reveal a south to southwesterly grouping with steep positive inclinations, directional scatter increases at all demagnetization levels above $10 \mathrm{mT}$ and $100{ }^{\circ} \mathrm{C}$. Comparison of demagnetization behavior of the weathered cobble samples with that of the in situ felsites unveils substantial differences. In addition to the previously noted lower NRM intensities and Koenigsberger ratios, the conglomerate cobbles have median destructive fields and temperatures of less than $10 \mathrm{mT}$ and 100 ${ }^{\circ} \mathrm{C}$, respectively. Several samples exhibit unstable behavior during demagnetization, none displaying the tightly linear trajectories observed in most of the Traveler samples. Also, heating in air at temperatures of $400{ }^{\circ} \mathrm{C}$ and above generates increases in bulk susceptibility to factors greater than 1,000 , a phenomenon never observed in the felsite itself. The deep weathering of the felsite cobbles noted by Rankin (1961) seems to have caused profound changes in their magnetic characteristics. We therefore cannot relate the seemingly random directional results from the conglomerate to the magnetization age of the subjacent felsite with any degree of confidence.

In summary, the magnetization of the 
Traveler Felsite is dominated by two major components: a low-coercivity, low-blocking temperature component parallel to the present field and a dual polarity remanence that can be isolated by either thermal or AF demagnetization. We propose that this second component, carried dominantly by magnetite, represents the characteristic magnetization of the Traveler Felsite. Other possible components are only rarely observed and are thought to be of minor significance. Normal and reversed polarities of the characteristic magnetization are stratigraphically zoned in our sample suite: reversed polarities are confined to the Pogy member and normal polarities to the superjacent Black Cat member. No other directions are observed in samples with stable magnetizations.

\section{RESULTS}

The site mean characteristic directions for the Traveler Felsite are listed in Table 1. Sites DTB and DTP are excluded from the formation mean calculations because they do not yield characteristic directions. Characteristic directions from sites DTF, DTH, and DTO were determined by a leastsquares fit of a straight line to three or more colinear points along demagnetization paths not trending to the origin. Directions for other sites are for the AF demagnetization step showing the best grouping of sample directions, although all samples were subjected to at least three progressive demagnetization steps to establish directional stability.

Inverting the reversed site directions for calculation yields an in situ formation mean of $\mathrm{D}=18.2, \mathrm{I}=-14.1, \mathrm{k}=16, \alpha_{95}=10.7$ for $\mathrm{N}$
$=13$ sites. A simple tilt correction (one-stage finite rotation about bedding strike by observed amount of dip) results in a slight, although statistically insignificant, improvement in the site mean grouping. Closer examination of the directions (Fig. 5) before and after the tilt correction reveals some complexities, however. First, the mean of the Pogy site mean directions is not antipodal to the mean of the Black Cat site means before correcting for tilt. This is seen by comparing mean inverted reversed $(\mathrm{D}=1.9$, $\left.\mathrm{I}=35.7, \alpha_{95}=17.5\right)$ and mean normal $(\mathrm{D}=$ $23.9, \mathrm{I}=-4.5, \alpha_{95}=5.2$ ) in situ directions and noting that the respective cones of confidence do not intersect. After tilt correction, there is overlap in the cones of confidence, and an F-ratio test (Watson, 1956) shows that the inverted reversed means and normal means do not differ at the $95 \%$ confidence level (that is, the Pogy and Black Cat means can be considered coaxial).

Second, although the grouping among reversed sites does not change significantly with tilt correction, dispersion among the normal sites becomes significantly greater at the $99 \%$ confidence level after simple tilt correction $\left(k_{1}=97.5, k_{2}=17.2\right)$. Two phenomena are thus observed in the in situ and corrected dispersion statistics: (1) an increase in dispersion among the normal site means, after correction, and (2) antiparallel normal and reversed means after correction. The former increases dispersion after tilt correction, and the latter decreases it, resulting in nearly equal $\mathrm{k}$ and $\alpha_{95}$ for the formation means before and after the corrections (Fig. 5).

Rankin's (1961) analysis of the temporal development of the volcanic complex and Hon and Roy's (1981) proposal of north- ward regional tilt suggest a two-stage method of restoring the directions to a paleohorizontal reference frame. The method is derived from the following reconstruction of events: (1) The tuffs of the Pogy member were deposited on a horizontal surface, and planar structures observed in the field are true bedding planes. (2) Caldera collapse resulted in deformation and tilting of these beds. (3) There was subsequent explosive eruption of the Black Cat tuffs on the deformed surface. This implies that the apparent bedding planes observed in the massive flows of the Black Cat member are primary structures reflecting deposition on a high-relief surface, possibly at substantial angles to the paleohorizontal, a phenomenon not unusual in currently active volcanoes (MacDonald, 1972). (4) Subsequent tilting of the whole formation took place during gentle folding about the Trout Valley syncline.

The two-stage method involves first unfolding directions of all sites around the Trout Valley syncline axis (restoring the Black Cat to paleohorizontal) and then applying a simple tilt correction around the residual bedding attitudes to only the site means of the Pogy member. Presumably, these residual attitudes represent the structures formed in the Pogy member during caldera formation, prior to the eruption of the Black Cat tuffs. This yields a formation mean of $D=26.7, I=22.4, k=19.2, \alpha_{95}=9.7$. A tighter grouping than either the in situ or simple tilt corrected directions is obtained and, at the same time, the antipolarity of normal and reversed directions is maintained. This correction scheme is valid only if the sample directions represent a primary magnetization and is thus a somewhat circu-

TABIE 2. PAL.EOMAGNETIC POLES USED FOR ANALYSIS

\begin{tabular}{|c|c|c|c|c|c|c|}
\hline Tectonic or rock unit & Age* & $\begin{array}{l}\text { L.at. } \\
\text { (S) }\end{array}$ & $\begin{array}{l}\text { Long. } \\
\text { E. }\end{array}$ & $\delta \mathrm{p}$ & $\delta \mathrm{m}\left(\mathrm{A}_{95}\right)$ & Reference \\
\hline \multicolumn{7}{|l|}{ I. Traveler Terrane } \\
\hline Traveler Felsite. ME & $D_{e}$ & (TF) $29^{\circ}$ & $262^{\circ}$ & 6. & 11 & This study \\
\hline Compton metasedíments, QUE & $D_{c}^{c}$ & (C) $20^{\circ}$ & $259^{\circ}$ & 3. & 6 & Seguin and others. 1980 \\
\hline Dockendorff Grp., ME & Post $406 \mathrm{Ma}$ & (DG) $20^{\circ}$ & $264^{\circ}$ & 4. & 8 & Brown and Kelly. 1980 \\
\hline \multicolumn{7}{|l|}{ 2. Laurentia } \\
\hline Bloomsburg Fm & $s_{1}$ & $32^{\circ}$ & $282^{\circ}$ & 6. & 10 & Roy and others. 1967 \\
\hline Middle-Late Devonian (mean) & $\mathbf{D}_{\mathrm{m}-1}$ & $50^{\circ}$ & $297^{\circ}$ & & (6) & Van der Yoo and Scotese, 1981 \\
\hline Early Carboniferous (mean) & $C_{e}^{m-1}$ & $44^{\circ}$ & $307^{\circ}$ & & (10) & Kent and Opdyke. 1979 \\
\hline \multicolumn{7}{|l|}{ 3. Acadia } \\
\hline Hersey and Eastport Fm & $s_{1}-D_{e}$ & $22^{\circ}$ & $302^{\circ}$ & 4. & 7 & Kent and Opdyke. 1980 \\
\hline Middle-Late Devonian (mean) & $\mathrm{D}_{\mathrm{ml}}^{\prime}$ & $28^{\circ}$ & $300^{\circ}$ & & (8) & Van der Voo and Scotese, 1981 \\
\hline Hopewell Girp. & $C_{e}$ & $36^{\circ}$ & $303^{\circ}$ & 1. & 3 & Roy and Purk. 1974 \\
\hline
\end{tabular}


lar argument; for this reason, we use only the simple tilt correction direction for polar wander considerations. Nonetheless, the two-stage correction seems an interesting exercise, giving results consistent with both the inferred structural evolution of the complex and the observed magnetizations.

\section{Age of Magnetization}

The use of paleomagnetic poles in the construction of apparent polar wander paths for the purpose of paleogeographic reconstruction requires knowledge of two variables: (1) a well-constrained direction of magnetization and (2) reasonable limits on the age of this magnetization. Although complications exist in structural corrections of the Traveler Felsite directions, note that formation mean directions (and corresponding poles) are similar for the in situ, simple tilt corrected, two-stage correction cases. Nonetheless, these same complications make it difficult to determine the age of magnetization. If we conclude that the magnetization dates to the age of the rock or that it is pre-Acadian folding, the age is well constrained. If, on the other hand, the remanence acquisition postdated the folding, no constraints on its minimum age exist. As detailed above, the fold test proves statistically inconclusive and the conglomerate test contributes no information relevant to the magnetization of the felsite. An argument for a postfolding remanence age can be made from the significantly increased dispersion among the Black Cat site means after simple tilt correction. Alternatively, there are several features of the data that imply a magnetization near the time of eruption and prior to Acadian folding.
These include: (1) the dual polarity set of characteristic directions, (2) a lithostratigraphic boundary between reversed and normal magnetozones, (3) the observation that site mean directions fail the reversal test before tilt correction but pass the test after correction, and (4) the difficulty of conceiving of a remagnetization mechanism that would have affected one of the two formation members and not the other or both in a manner that could have produced the observed magnetization pattern.

Although the results are somewhat conflicting, we feel the evidence is more heavily weighted toward a prefolding age of magnetization, based on the above arguments.

\section{COMPARISON WITH OTHER PALEOMAGNETIC DATA}

Paleomagnetic poles from Lower Devonian rock units of the New England Appalachians are listed in Table 2 and plotted in Figure 6. Results from intrusive rocks have not been included, for reasons discussed below. Note that the only pole that is close in age and that can be unambiguously associated with cratonic Laurentia (North America west of the easternmost exposures of Grenville basement) is from the Late $\mathrm{Si}$ lurian Bloomsburg Formation (Roy and others, 1967). The Hersey and Eastport poles have been associated with the Acadia APW trend, which is different from the Laurentia path from Middle Devonian through early Carboniferous time. Poles $\mathrm{TF}, \mathrm{C}$, and DG come from rock units in northern Maine and southern Quebec and form a tight grouping that is far from Late Silurian-Early Devonian poles of the proposed Acadia terrane and also significantly distant from the Bloomsburg pole.

Brown and Kelly (1980) demonstrated a postfolding magnetization in the Dockendorff Group volcanics (DG). They tentatively interpreted the age of magnetization as coeval with the Acadian orogeny, which in northern Maine is stratigraphically constrained to be of late Early to early Middle Devonian age. It is interesting to note the good agreement between this pole and the Early Devonian poles TF and C ( $\mathrm{C}$ has been shown to antedate Acadian folding).

One other result from this region that is not included in this comparison is the pole from the St. Frances metasediments (Seguin, 1980) of southeastern Quebec. The pole $\left(24^{\circ} \mathrm{S}, 329^{\circ} \mathrm{E}\right)$ is based on only three sites, dispersion is large $\left(\alpha_{95}=32^{\circ}\right)$, the age is poorly constrained (post-Ordovician, apparently pre-Acadian metamorphism), and, lastly, the pole itself is far from other SiluroDevonian poles from the northeast. We doubt this result is representative of the Early Devonian magnetic field for this region.

Comparison of APW paths over an extended time period rather than of isolated poles is a useful technique for discerning relative tectonic motions responsible for apparent polar shift. For Silurian to Middle Devonian time, however, this is a difficult if not impossible task, given the existing data set. Although Middle Devonian through
Figure 6. Paleomagnetic (south) poles and apparent polar wander paths for results from middle Paleozoic bedded rocks from eastern North America. Triangular symbols are: C = Compton Formation, DG = Dockendorff Group, $\mathbf{T F}=$ Traveler Felsite, $\mathbf{P R}=$ lower Carboniferous red beds from northwestern New Brunswick. APW paths for Late Silurian (Sl) to late Carboniferous (Cl) Laurentia (filled symbols) and Acadia (open) after Kent and Opdyke (1980). See Table $\mathbf{2}$ for compilation sources. The tentative join between the Late Silurian and Middle to Late Devonian for Laurentia reflects the lack of Late Silurian-Early Devonian paleopoles and is shown as a dotted line. The late Carboniferous mean pole is assumed to be representative of both Acadia and Laurentia (Van der Voo and French, 1974).

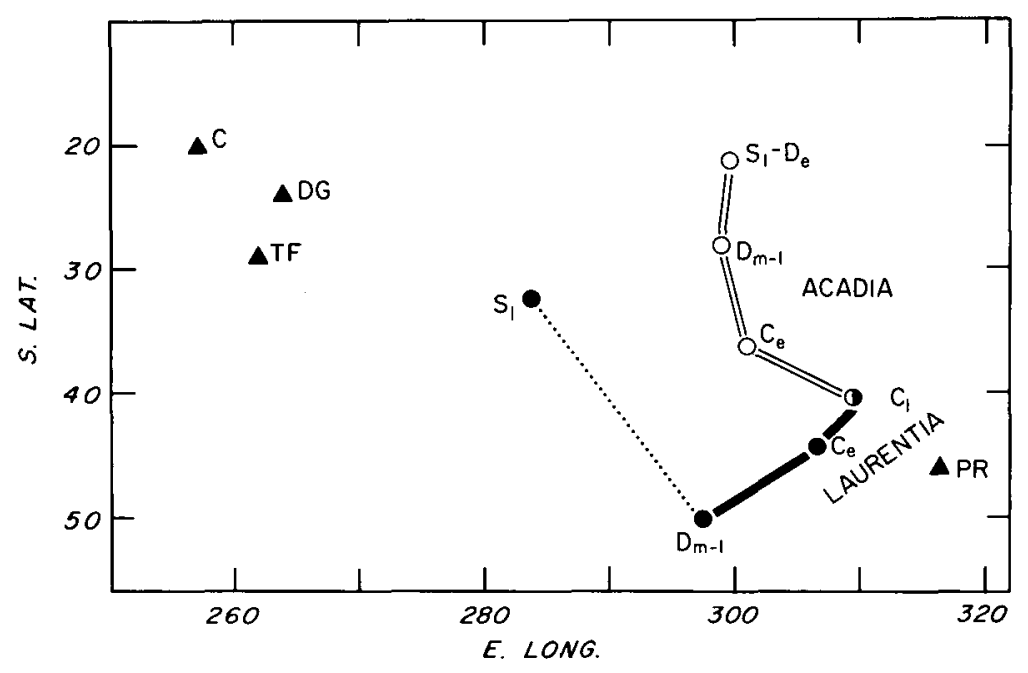


Figure 7. A schematic representation of the proposed rotation of a "traveler terrane" with respect to Laurentia based on paleomagnetic poles. a. C, DG, and TF arrows represent Compton, Dockendorff, and Traveler north directions on their sampling localities rotated into agreement with DLa, a paleo-north for Early Devonian Laurentia calculated from the Bloomsburg pole. Thrust fault symbols are two possible locations of subduction zones invoked to explain the Siluro-Devonian arc volcanic belts (stippled). b. C, DG, and TF are rotated clockwise into their present configuration by early Carboniferous time, as shown by the agreement between the Plaster Rock direction and the early Carboniferous Laurentia paleo-meridian (CeLa). Proposed transcurrent motion of Acadia may have been under way at this time, possibly along the Norumbega and Clinton-Newberry (C-N) faults. Note that the longitudinal relationship between the Traveler block and Laurentia and the pole of rotation are not constrained by paleomagnetic results and so are arbitrarily represented in this drawing.

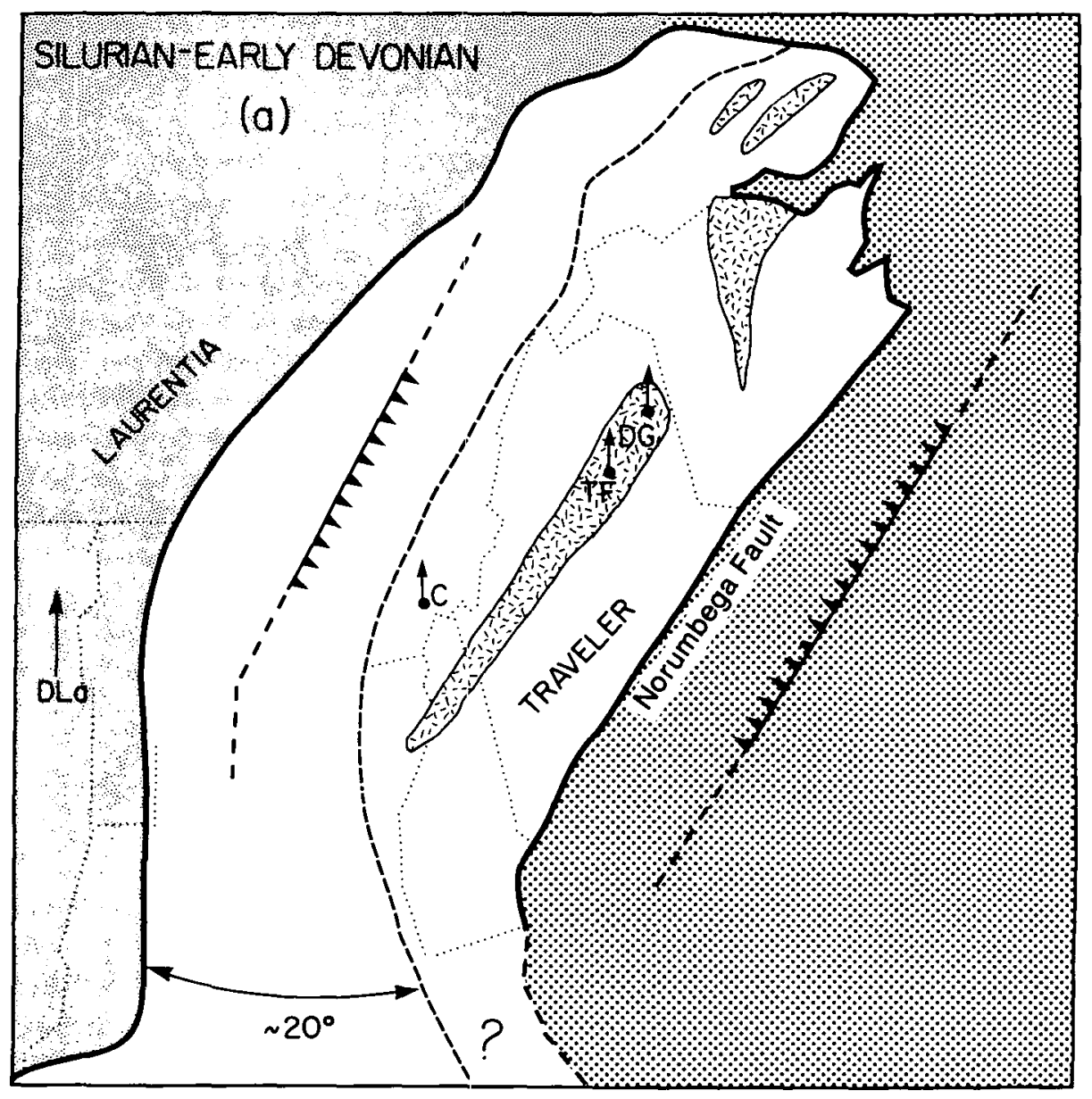

late Carboniferous poles separate into the aforementioned Laurentia-Acadia paths, for several reasons it is difficult to make analogous distinctions for earlier periods. We note a distinct grouping of poles for the southeastern Quebec-northern Maine region, but there are no Early Devonian poles that can be unambiguously associated with Laurentia for direct comparison, and we are forced to use the Late Silurian pole from the Bloomsburg Formation. Secondly, the large scatter in earlier Silurian poles both from Laurentia and from the Appalachians precludes construction of a well-constrained APW path. Thus, although Silurian poles from the Botwood Group of Newfoundland (LaPointe, 1979) and the Late SilurianEarly Devonian poles from the Hersey and Eastport Formations have been proposed as an older extension of the Acadia trend (Kent and Opdyke, 1980), Silurian poles from North America are scattered over a wide range of latitudes and longitudes east of $285^{\circ} \mathrm{E}$ long. in Figure 6. Despite these limitations, it is still possible to examine several distinctive features of these data. First, the Compton-Traveler-Dockendorff grouping clearly lies off the Acadia APW path. This difference is primarily in longitude and could be explained by a $20^{\circ}$ to $30^{\circ}$ clockwise rotation of northern Maine relative to Acadia. Secondly, although to a lesser degree, the same rotational displacement exists between this group and the Bloomsburg paleopole. Note that consideration of other Silurian North American poles emphasizes this effect; they all lie to the east of the Bloomsburg pole. Likewise, comparison with the Middle to Late Devonian average for Laurentia suggests the same clockwise displacement. Moreover, the dispersed sampling locales of poles TF, $C$, and DG imply that the rotational displacement affected a large region. Separate, local tectonic rotations are unlikely to have produced the observed pattern.

The lack of an Early Devonian pole for Laurentia prohibits resolution of significant paleolatitude differences between northern Maine-southern Quebec and either Laurentia or Acadia. Late Silurian-Early Devonian paleolatitudes, all corrected to the Traveler Formation locality, are $\sim 15^{\circ} \mathrm{S}$ for the Traveler-Compton-Dockendorff mean, $\sim 12^{\circ} \mathrm{S}$ for Laurentia (Bloomsburg pole), and $\sim 20^{\circ} \mathrm{S}$ for Acadia (Hersey-Eastport pole). The Traveler-Compton-Dockendorff paleolatitude is not substantially different from paleolatitudes inferred for either Laurentia or Acadia, although marginally in better agreement with the paleolatitude for Laurentia.

It is fair to point out that we have excluded from this analysis several paleomagnetic results from intrusive rocks in the northern Appalachians (Roy and others, 1979; Rao and others, 1981; LaPointe, 1979). Poles from these units are widely scattered and simply do not fit into a consistent plate-tectonic interpretation of apparent polar wandei. For a more detailed discussion of this problem, the reader is 


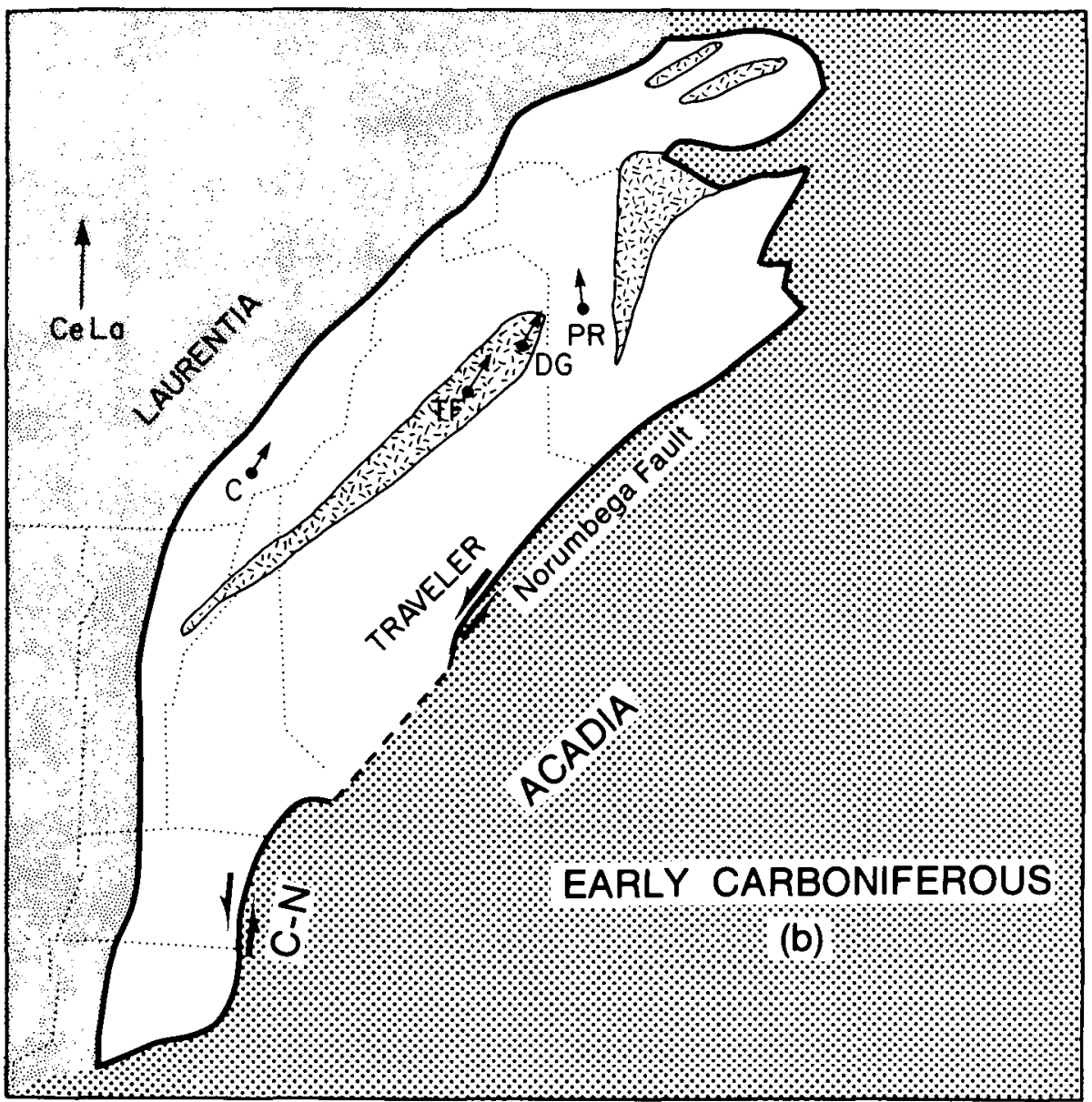

referred to Roy (1982) and Kent and Opdyke (1982).

\section{TECTONIC AND \\ PALEOGEOGRAPHIC IMPLICATIONS}

Although the hypothesis remains unconfirmed that the observed pattern of paleopole groupings in Figure 6 represents real distinctions among Laurentia, Acadia, and a "Traveler" block, it can be examined in conjunction with tectonic and paleogeographic models based on the bedrock geology. Briefly, this hypothesis proposes that the Traveler terrane, covering at least the area subtended by the Traveler-ComptonDockendorff triangle, rotated $20^{\circ}$ to $30^{\circ}$ clockwise relative to Laurentia and Acadia at some time after the Early Devonian, as implied by the location of this mean pole with respect to the Bloomsburg pole (Roy and others, 1967) and the Middle to Late Devonian Laurentian mean (Fig. 6). Timing of this rotation can be constrained paleomagnetically by a result from lower Carboniferous red beds of the Plaster Rock subbasin, New Brunswick (PR in Fig. 7b). These red beds are $70 \mathrm{~km}$ northeast of the Dockendorff sites and yield a pole in close agreement with Laurentia for either early or late Carboniferous time (Spariosu and Kent, 1980, 1981). Acadian deformation and metamorphism in the New England Appalachians occurred during the Middle Devonian, within the time frame of the apparent rotation constrained by paleomagnetics.

A minimum size for the Traveler block can be inferred from the location of the $\mathrm{C}$, TF, and DG sampling localities (Fig. 7). Lithostratigraphic correlations along the Appalachian orogen (Rodgers, 1970; Williams. 1978), however. suggest the block may be much larger. Three maior belts that extend through this arcuate segment of the orogen are the Connecticut Valley-Gaspé Synclinorium, the Bronson Hill Anticlino-
Figure 7. (Continued)

rium, and the Merrimack Synclinorium (Fig. la). If the Traveler block is coextensive with these features, it may be continuous from Long Island Sound north to Chaleur Bay (Figs. 7a, 7b). The northwest boundary of the terrane is not obvious.

The structural expression of an inferred Middle to Late Devonian clockwise rotation of the Traveler block will depend on the location of the Euler pole of rotation. If it lies to the south of the terrane, one would expect to see evidence of extension along the Traveler-Laurentia boundary. Conversely, if the pole of rotation is to the north, compressional tectonics should be associated with the rotation. The Acadian deformation is compressional everywhere in the northern Appalachians, and thus it seems more likely that the rotation is accommodated by convergence between the Traveler block and Laurentia. The pivot point shown in Figures $7 \mathrm{a}$ and $7 \mathrm{~b}$ is arbitrarily chosen to imply minimum convergence. Another implication of this geometry is that relative convergence must increase southward along the margin. Compatible geological evidence includes:

1. The generally increasing grade of Acadian regional metamorphism from subgreenschist in the Gaspe and Chaleur Bay areas in the north to upper amphibolite grade southward in Connecticut and Massachusetts (Rodgers, 1970).

2. Basement remobilization and partial melting of crustal rocks are evident in the Bronson Hill Anticlinorium and Merrimack Synclinorium to the south but less so to the north (Rodgers, 1970).

3. Compression-related structures suggest a great deal more east-west shortening southward; nappes are refolded isoclinally, as evidenced by inverted isograds (Robinson and Hall, 1980); and the older Paleozoic tectonostratigraphic zones appear to be more foreshortened (Williams, 1978). Although much shortening occurs in the north, the structures are simpler and show a lesser degree of westward transport.

4. A collision of Laurentia with the Traveler block is in general agreement with the models of the Acadian orogeny by Robinson and Hall (1980) across Massachusetts 
and by Hon and Roy (1981) for a section through Maine. Also, the proposed Traveler block closely parallels an assemblage of Osberg's (1978) basements C and B, both distinct from Laurentian Grenville basement to the west and Avalon basement to the east, although he proposes accretion in the Ordovician rather than in the Devonian.

We have outlined above how some of the deformational features within the proposed Traveler terrane and adjacent Laurentia are consistent with a clockwise rotation and Middle Devonian convergence. On the other hand, large-scale thin-skinned thrusting of parts of the Traveler block and/or parts of the Laurentian margin could accompany the postulated rotation. Whether thin-skinned or internal deformation dominates the convergence-related structures remains unknown, pending further deepseismic reflection research and/or a better understanding of the pre-Middle Devonian geography of the New England region.

In any case, it seems unlikely that the Traveler terrane was associated with the Acadia displaced terrane before its rotation and accretion to the Laurentian margin. Paleomagnetic results indicate that Acadia was about $1,500 \mathrm{~km}$ south of its present position relative to Laurentia in the Middle to Late Devonian and that it did not attain its present position before the late Carboniferous. If the Traveler block originally was part of Acadia, a post-Early Devonian, pre-Early Carboniferous separation of the Traveler terrane from Acadia and subsequent northward motion are required before its rotational emplacement adjacent to Laurentia. Apart from the tectonic complexities presented by this scenario, the depositional contact (in places) between Silurian rocks of the Connecticut ValleyGaspe Synclinorium and deformed Ordovician rocks of the early Paleozoic North American margin argues for a more proximal relationship between the Traveler terrane and Laurentia. In fact, neither the paleomagnetic nor the geologic evidence suggests that the Traveler block is "exotic" to North America during the SilurianDevonian, only that relative convergence between them during the Devonian has a rotational component.

The above paleomagnetic and geologic information can be assembled into a platetectonic and paleogeographic model of the New England Appalachians (Fig. 7). Beginning in Silurian time, deep basinal deposition of turbidites dominates between Laurentia and the Traveler block. It is not clear whether this basin forms on oceanic or continental crust, although geophysical evidence indicates that it is certainly not Grenville basement (Taylor and Toksoz, 1982). Subduction begins in Late Silurian to Early Devonian time, resulting in formation of the Piscataquis and Matapedia volcanic arcs. Whether this subduction is eastdipping, west-dipping, or first one and then the other (as suggested by Hon and Roy, 1981) remains unclear. Convergence between the plates peaks in late Early to early Middle Devonian time as the Traveler block rotates into its present configuration with respect to Laurentia, culminating in latestage deformations, basement remobilization, regional metamorphism, and, finally, granitic plutonism.

It is clear that more paleomagnetic data are needed to test the hypothesis of a distinct Traveler block. Paleomagnetic poles from older rock units in the region would permit construction of an apparent polar wander path to compare with that from Laurentia and Acadia over longer periods of time. Also essential for confirmation of this type of motion is a more tightly constrained APW path for Laurentia for the Silurian-Early Devonian time span. Recognition of the role of small-scale plates and motions in the evolution of the Appalachian orogen depends on better paleomagnetic definition of Laurentian poles from early to middle Paleozoic time.

\section{ACKNOWLEDGMENTS}

J.E.T. Channell, J. T. Engelder, and R. A. Schweickert reviewed earlier versions of the manuscript. P. Brown and an anonymous reviewer suggested several improvements. We thank Scott Opdyke for field assistance and Walter Anderson of the Maine Geological Survey and A. Lee Tibbs for help in gaining access to Baxter State Park. This work was funded by National Science Foundation Grant EAR 80-07748. Funds for field work by Spariosu were also provided by Geological Society of America Grant 2537-79.

\section{REFERENCES CITED}

Bottino, M. L.. Schnetzler, C. C., and Fullager. P. D., 1965, Rb-Sr whole rock age of the Traveler and Kineo rhyolites, Maine, and its bearing on the Early Devonian [abs.]: Geological Socicty of America Special Paper 87. p. 15.

Brown, L. L., and Kelly, W. M. 1980. Paleomagnetic results from Northern Maine Reinterpretations: Geophysical Research l.etters, v. 7.p. $1109-1111$.

Caldwell. D. W.. 1972. The geology of Baxter State Park and Mt. Katahdin: Maine Geological Survey Bulletin 12,57 p.

Dorf. E., and Rankin. D. W.. 1962. Early Devonian plants from the Traveler Mountain area, Maine: Journal of Pateontology, $v$. 36. p. 999-1004.

Graham, J. W.. 1949. The stability and significance of magnetism in sedimentary rocks: Journal of Geophysical Research, v, 54 , p. 131-167.

Hon, R., and Roy, D. C., 1981, Magmatogenic and stratigraphic constraints on Acadian tectonism in Maine [abs.]: Geological Society of America Abstracts with Programs, v. 13, p. 138.

Irving. E., 1979. Paleopoles and pateolatitudes of North America and speculations about displaced terrains: Canadian Journal of Earth Sciences, v. 16, p. 669-694.

Kent, D. V., and Opdyke, N. D., 1978, Paleomagnetism of the Devonian Catskill redbeds: Evidence for motion of coastal New England-Canadian Maritime region relative to craconic North America: Journal of Geophysical Research, v. 83, p. 4441-4450 1979. The Early Carboniferous paleomagnetic field for North America and its bearing on tectonics of the northern Appalachians: Earth and Planetary Science Letters, v. 44. p. 365-372. 1980. Paleomagnetism of Siluro-Devonian rocks from eastern Maine: Canadian Journal of Earth Sciences, v. 17, p. 1653-1665. Maine: Canadian Journal of Eanth Sciences, v. 17, p. 1653-1665. Maine: Reply: Canadian Journal of Earth Sciei.ces, v. 19. p. 232-237.

LaPointe, P. L., 1979. Paleomagnetism and orogenic history of the Botwood Group and Mi. Peyton batholith. Central Mobile Belt. Botwood Group and Mi. Peyton batholith. Central Mobile Belt.
Newfoundland: Canadian Journal of Earth Sciences, v. 16, p. 866-876.

MacDonald, G. A., 1972. Volcanoes: New Jersey, Prentice-Hall. $510 \mathrm{p}$ Osberg. P. H., 1978, Synthesis of the geology of the northeastern Appalachians, U.S.A., in IGCP Project 27, Caledonian-Appalachian orogen of the North Allantic region: Geological Survey of Canada Paper 78-13, p. 137-148.

Rankin. D. W., 196I. Bedrock geology of the Katabdin-Traveler area, Maine [Ph.D. thesis]: Cambridge, Massachusetts. Harvard University. $317 \mathrm{p}$.

1968, Volcanism related to tectonism in the Piscatayuis Volcanic Belt, an island arc of Early Devonian age in north-central Main. in Zen. E-An, and others, eds. Studies of Appalachian geology. northern and maritime: New York, Interscience. p. 355-369.

Rao, K. V., Seguin, M. K., and Deutsch, E. R., 1981, Paleomagnetism of Siluro-Devonian and Cambrian granitic rocks from the Avalon Zone in Cape Breton Island, Nova Scotia; Canadian Journal of Earth Sciences, v. 18, p. 1187-1210.

Robinson. P.. and Halt, L. M., 1980. Tectonic synthesis of southern New England, in IGCP Project 27. Proceedings: "The Caledonides in the U.S.A." Virginia Polytechric Institute memoir 2. p. $73-82$.

Rodgers, J.. 1970. The tectonics of the Appalachians: New York, John Wiley and Sons. $271 \mathrm{p}$.

Roy, J. L.. 1982, Paleomagnetism of Siluro-Devonian rocks from eastern Maine: Discussion: Canadian Journal of Earth Sciences. v. 19. p. 225-232.

Roy. J. L., and Park. J. K., 1974. The magnetization process of certain red beds: Vector analysis of chemical and thermal results: Canadian Journal of Earth Sciences. v. 11. p. 437-471.

Roy, J. L., Opdyke, N. D., and Irving. E., 1967, Further paleomagnetic results from the Bloomsburg Formation: Journal of Geophysical Research, v. 72, p. 5075-5086.

Roy. J. L. Anderson. P.. and LaPointe. P. L.. 1979, Paleomagnetic results from three rock units of New Brunswick and their bearing on the lower Pateozoic tectonics of North America: Canadian Journal of Earth Sciences, v. 16, p. 1210-1227.

Seguin. M. K.. 1980. A case of multiphase magnetization in the Weedon-Gould area: Annales de Géophysique, v. 36. p. 73-84.

cguin, M. K.. Rao, K. V., and Pineault, R.. 1980, Devonian paleomagnetic poles from the St. Cecile and St. Sebastien metasediments and hornfels: Gaspé-Connecticut Valtey Synclinorium, Quebec [abs.]: EOS (American Geophysical Union Transactions), v. 61 , p. 220.

Spariosu. D. J., and Kent. D. V.. 1980. Pateomagnetic results from northern Maine and their bearing on displaced terrains [abs.]: EOS (American Geophysical Union Transactions). Y. 61. p. 220. 1981. Paleomagnetism of lower Carboniferous redbeds and vol-
canics from western New Brunswick [abs.]: EOS (American canics from western New Brunswick [abs.]:
Geophysical Union Transactions), v. 62, p. 264

Taylor. S. R.. and Toksoz. M. N.. 1982. Crust and upper-mantle velocity structure in the Appalachian orogenic belt: Implications for tectonic evolution: Geological Society of America Bulletin, v. 93, p. 315-329.

Van der $V_{0 o}$, R.. and French. R. B., 1974. Apparent polar wandering for the Allantic-bordering continents: Late ${ }^{\circ}$ Carboniferous to Eocene: Earth-Science Reviews, v. 10, p. 99-119.

Van der Yoo. R., and Scotese. C., 1981. Paleomagnetic evidence for a large $(\sim 2000 \mathrm{~km})$ sinistral offset along the Great Glen fault during Carboniferous time: Geology, v. 9. p. 583-589.

Van der Voo. R., French, A. N., and French, R. B., 1979, A paleomagnetic pole position from the folded Upper Devonian Catskill redbeds, and its tectonic implications: Geology. v. 7. p. 345-348.

Watson. G. S.. 1956. Analysis of dispersion on a sphere: Monographs and Notices of the Royal Astronomical Society. Geophysical Supplement, v. 7. p. 153-159.

Williams, H.. 1978. Tectonic lithofacies map of the Appalachian orogen: Memorial University of Newfoundland, Map no. I, scale I:1,000,000.

Zijderveld. J.D.A.. 1967. A. C. demagnetization of rocks: Analysis of results, in Collinson, D. W.. Creer, K. M., and Runcorn, S. K. eds.. Methods in paleomagnetism: New York, Elsevier, p $254-286$ MANISCRTP RECENED HY tHE SOCJETY MAY 14, 1982 MANisCR!Pt ACCEPTED OCTOBER 29, 1982 M.AMONT-DOHERTY GEOH.OGICAL OBSER ATORY CONTRIBI'TION NO. 3486 